\title{
1.3. ENVIRONMENTAL FINANCING IN THE EUROPEAN UNION AND UKRAINE
}

\begin{abstract}
Summary
The aims of this paper are to analyze and estimate the financing system of environmental protection in Ukraine and studying the experience of EU countries. Analyzing the costs used for environmental protection activities will give an idea about that which funds, in which way - directly or indirectly - in which sectors spent money for environmental protection. The efficiency of financing the environmental activities may be estimated by the impacts of financing the measures on reducing pollution.

In coming years, the development of financing the improvement of ecologic situation in Ukraine is associated with the development of environmental funds. Currently in Ukraine, a number of state-operated environmental funds are in operation. These funds were formed at the expense of the environmental taxes, fees for special use of natural resources, penalties for violation of rules and regulations on the protection of the environment and the damage caused a violation of the legislation of environmental protection. Mentioned taxes and fees will lead exclusively fiscal direction and will ignore regulatory, a restrictive and stimulating functions that is not conducive to the effective use of natural or ecological benefits of social production.
\end{abstract}

Keywords: environmental protection, environmental protection expenditures, ecological payments

\section{Introduction}

The main aim of this paper is to analyze and evaluate the financing system of environmental protection in Ukraine and studying the experiences of EU countries. The financing system of environmental protection will show us what funds, in which way - directly or indirectly - spent money in which sectors for environmental protection. The efficiency of financing the environmental activities may be estimated by the quantitative impacts of environmental activities on reducing pollution.

We have read the scientific works about the potential dangers of the future. Global warming is real hazard; we shall consider its possible negative effects. We have heard the warnings, and unless we act now, we will face serious consequences. The good news have nearly lost in the debates, that we can do something, and more easily, and at far less cost, than most of us could imagine.

In this process, it may help to have a vision of how the future might look if we succeed. That is not merely a cleaner, healthier, more secure world for all. Handled correctly, our fight against global warming could set the stage for an eco-friendly transformation of the global economy - one that spurs growth and development rather than crimps it, as many nations fear.

We have witnessed three economic transformations in the past century. At first, the Industrial Revolution occurred, and then the technology revolution came, then our 
modern era of globalization. We stand at the threshold of another great change: the age of green economics. (Ban Ki-moon, 2007)

In coming years, the improvement of the ecological situation in Ukraine is associated with the development of environmental funds. In Ukraine, a number of state-financed Environmental Funds have been established and still are in operation. Mentioned funds are formed at the expense of environmental taxes, fees for special use of natural resources, penalties for violation of rules and regulations on the protection of the environment and the damage caused a violation of the legislation on environmental protection. Mentioned taxes and fees will carry exclusively fiscal direction and will ignore regulatory, restrictive and stimulating functions that are not conducive to the effective use of natural or ecological benefits of social production.

Environmental protection expenditure is the money that society spends on protecting the environment. Nowadays, the protection of the environment is integrated into all policy fields with the general aim of reaching sustainable development. Clean air, water and soils, healthy ecosystems and rich biodiversity are vital for human life, and thus it is not surprising that our societies devote large amounts of money to curbing pollution and preserving a healthy environment.

Environmental protection expenditure (EPE) is that amount of money which is spent on activities directly aimed at the prevention, reduction and elimination of pollution resulting from the production or consumption of goods and services. These are, for example, waste disposal activities and wastewater treatment activities, as well as activities aimed at noise abatement and air pollution control. Environmental protection expenditure does not directly take into account the expenditure for the sustainable management of natural resources (Environmental statistics and accounts in Europe, 2010).

All economic sectors and businesses in agriculture, industry and services as well as in the public sector and households spend some money on reducing, preventing and eliminating their pressures on the environment. For instance, both businesses and households pay for disposing the waste in a safe way, production activities spend money to mitigate the polluting effects of production processes and governments pay to provide environmental public goods, such as the basic levels of sanitation required to safeguard health. Governments subsidise the environmentally beneficial activities and use public funds to make it easier to borrow money on the financial markets for environmental projects, through measures such as risk sharing, credit enhancement or subsidies to lower the costs of borrowing in communities that cannot afford the full costs of investments for environmental projects. The demand for goods and services to prevent or treat environmental damages due to socioeconomic activities coming from the growing expenditure the economy will encourage the supply of environmental goods and services and stimulates the development of a 'greener' economy in all sectors.

This chapter provides details on the expenditure carried out by three sectors: public sector, private and public specialised producers and industry. These sectors account for most of the environmental expenditure. The public sector includes mainly central, regional and local public administration. Specialised producers are public or private businesses that provide environmental services, such as waste or wastewater 
management, as their principal output. Industry includes all activities in mining and quarrying, manufacturing and electricity, gas, and water supply sectors. Apart from legislative and regulatory tasks, the public sector monitors environmental performance, provides grants and subsidies to encourage environmentally sensitive behaviour and funds research and development activities.

In most European countries, public administrations, such as municipalities, can also provide environmental protection services, such as waste management or wastewater treatment, directly. These services are generally provided by public corporations, whose activities are differentiated from other governmental administrative tasks. In some countries, however, governments delegate the provision of environmental services to private or (semi-)public corporations whose main activity is directly aimed at protecting the environment. These corporations are called specialised producers and they provide public utility services and typical environmental services, such as waste and wastewater management and soil protection and remediation, as their principal output. The specialised producers are then either public or private corporations. Industry also plays a role in the protection of the environment. Most industrial activities take internal measures to reduce the environmental impact of their production processes: they invest in cleaner technologies to reduce emissions into air, water and soil and they organise their own waste management services, etc.

The analysis of spending on environmental protection has a strategic interest. For example, it allows the evaluation of the positioning of environmental policies already in place with respect to reference models such as the 'polluter pays' principle. For example, the growth of government-supported environmental expenditure can indicate a situation in which the government, rather than polluters, increasingly intervenes in the environment, and is therefore often indicative of a reality in which this principle is insufficiently applied.

At the same time, a low level of expenditure does not necessarily mean that a country is not effectively protecting its environment. In fact, the indicator tends to emphasise clean-up costs at the expense of cost reductions, which could be due to reduced emissions or more effective protection measures. Environmental expenditure may be broken down in order to analyse its main components. Total EPE is the sum of investments and current expenditure for industry and specialised production sectors, and the sum of investments, current expenditure and subsidies/transfers in the public sector.

Current expenditure includes recurrent spending or, in other words, spending on items that are consumed and only last a limited period of time. These are items that are used up in the process of providing a good or service. Current expenditure would include wages, salaries and expenditure on consumables. Investments are tangible fixed assets created to protect the environment from harmful impacts occurring during the production process. Examples of investments from the waste management sector are storage facilities and collecting points, separation plants and shredders and crushers. Environmental expenditure can also be classified according to which environmental domain is the objective of the expenditure: protection of ambient air and climate (air protection thereafter), wastewater management, waste management, protection and remediation of soil, groundwater and surface water, noise and vibration 
abatement, protection of biodiversity and landscapes, protection against radiation, research and development and other environmental protection activities. Air, wastewater and waste are often referred to as the core domains. The other environmental domains are grouped as the non-core domains.

Today of humanity critically faces the problem of overcoming the consequences of pollution of environment.

Like any other country, Ukraine did not avoid this problem. Problems with the state of environment arose as a result of activities both inside the country and beyond its borders. For this reason, the state is forced to carry out financing of measures on the removal of negative consequences for environment inflicted not only in the country but also abroad.

In the past, comprehensive environmental management has often been seen as a priority of the international donor community. Developing countries rightly claimed that development was the first priority and that during this process part of the protection of the environment should be paid for by the international community.

This perception has changed greatly over recent years. Few will be now in doubt that a healthy environment is the key for socio-economic development, and that environmental degradation can undermine and even reverse economic benefits. The current climate change debate is a good illustration of this strong awareness that sound environmental management is a condition sine qua none sustained economic growth is not possible.

\section{Material and method}

Many developing countries have made great strides in incorporating environmental management in their daily activities. These efforts should be supported and augmented. Environmental financing can no longer be seen as a donor supported activity but must become a part of national budgets and international financing.

Developed countries spend between $3 \%$ and $5 \%$ of their GNP on environmental management. In many developing countries, this percentage is less than $1 \%$. Moving from $1 \%$ to $3 \%$ cannot been done in short terms, and a systematic process needs to be put in place that gradually, perhaps taking 10-15 years, will introduce the necessary institutional, regulatory, legal, and market based changes that will enable countries to fulfil their own environment management needs. The question is how should the international community help countries achieve this transition?

Official development assistance (ODA) funds in the past have often been used to help countries to address their most urgent environmental needs. This help shall be continued and additional resources need to be made available to help countries in the further transition from an environmental financing system that is depending on support to an environmental financing that is part of the national and local budgets.

New and additional ODA funds should be directed towards helping countries to access, integrate and sequence the different international environmental funding sources to redirect domestic (public and private) and international (IFI and private) funding towards sustainable investments (http://www.oecd.org/dac/environmentdevelopment). 
The time for this shift of paradigm is due at the present because of two reasons:

- We have the knowledge, the tools and the experience.

- The emerging financing system against climate change problems offers a unique opportunity to make this shift.

Five critical steps are needed to make the paradigm shift at the national level.

Step 1: Comprehensive review: National reviews of all environmental flows are needed, for incomes and expenditures, and covering domestic and international financing, from both public and private sources. The methodology for carrying out such comprehensive review in an inclusive manner already exists; it has been tested and can be applied.

Step 2: Realistic, long term planning. Based on the review and the available environmental finance toolbox, comprising more than 360 tools, from taxes and subsidies to municipal bonds and public private partnerships, realistic, doable plans need to the developed to set in place the institutional, regulatory and market based changes that are needed to move over time to sustainable domestic financing. Quick wins should be identified to provide the political support for the changes.

Step 3: Well considered investment plans, that helps countries move forward towards long-term sustainability and the achievement of the MDGs.

All too often, the investment decisions are divorced from the strategic planning decision and they are governed by different processes and interests. A much closer relationship is needed between sustainable development planning and investments, including foreign direct investment, trade, technology choices etc.

Step 4: Sound pre-investment studies and project pipelining: To move towards sustainability, alternative solutions need to be considered prior to making the investment decisions, particularly in light of the challenge to address climate change. Business as usual might provide the quickest short term returns on investments but might not represent the most sustainable solutions or longer term benefits. More effort needs to be devoted to assess and implement alternative investment solutions that serve the double dividend: economic growth and poverty reduction.

Step 5: Redirect international development aid to support countries to make this paradigm shift. Considering the plethora of development demands, many countries do not have the resources to initiate, let alone to institutionalize, this paradigm shift. While not overly expensive, new and additional resources are needed to assist countries. The UN is uniquely positioned to deliver this support, but this will require a shift in the way the UN conducts its business.

In addition, five concomitant actions are proposed by UNDP (United Nations development Programme):

Action 1: Move to a continuum in service delivery: from policy planning and capacity development to investments and their evaluation. The need to integrate all environmental finance sources and align it with development goals at the national level, should be mimicked at the international level. A closer cooperation between the GEF and the UN supported programmes at the national level is emerging. This closer cooperation and integration of all development support, from policy setting to investments, should receive priority attention, particularly at the national level, and in the emerging response to climate change. 
Action 2: A new compact between the IFIs (International Financial Institutions) and the United Nations. The current agreement on how the UN works with the World Bank stems from 1946. Surely, there are compelling reasons to review this agreement. The $\mathrm{UN}$ is the only global system where all countries, donors and beneficiaries sit around the table as equal members. A privileged positioning and role that many financial institutions do not enjoy. Combining the development expertise of the UN with the investment expertise of the IFIs might result in a quantum leap forward in achieving the Millennium Development Goals (MDGs).

Action 3: A coherent delivery of environmental finance and investment support by all international development agencies, IFI, UN, bilateral donors, the NGOs and private sector. Currently great strides are being made to improve the capacity of the UN to deliver as one. This initiative should urgently be expanded to involve the financial mechanisms. The UNDG (UN Development Group) system at the national level could be expanded to incorporate all major financial actors, so as to provide e an integrated response to the country priority needs; it is incompliance with the Paris declaration on aid effectiveness.

Action 4: A strengthened system of international environmental finance support at the national and regional level. The current capacity of the UN to implement the suggested comprehensive and integrated financial support to countries is rather limited. The knowledge and expertise, in my assessment, certainly exist in UNDP, but the "boots on the ground" to deliver it is just not there. The demand is great; the supply site is stretched to a maximum.

Action 5: A watchdog function. To keep us honest and to provide guidance to public and private sector investors, a watchdog body, along the lines of Transparency International might need to be set up. We need to know where the major flow of finance is going and if it is directed towards sustainability and less carbon intensive development paths. We need to keep ourselves accountable and honest and review our actions to ensure the sustainability of the Earth.

The climate change challenge offers us the opportunity to do it. The cost to set up such a regime is modest compared with the costs that will be incurred if we continue to lack an improved environment finance management system by 2020. UNDP, as part of a cohesive UN wide response to the climate change challenge and in full cooperation with other UN agencies, is preparing itself to respond in a pro-active and coherent manner to these emerging opportunities and to position itself as the development agency that promotes, supports, catalyses and coordinates the establishment of longterm sustainable environmental financing practices at the national and local level. To be successful, the extensive expertise from different parts of the UN system needs to be called in. For example the FAO expertise with the FAO Investment Centre and forest and land management, the UNIDO technological expertise, the UNEP work on developing alternative technological and financial approaches.

UNDP can be the trusted and needed partner of national and local governments to help governments: (1) put long term sustainable environmental finance mechanisms in place, (2) decide on long term sustainable investments, amongst others through providing governments with (a) sustainable alternatives to business as usual (b-a-u), (b) conducting pre-investment studies, (3) developing project pipelines for private 
sector implementation; and (4) providing governments with the necessary tools, expert networks and capacity to make sustainable choices. This, I believe, is what is needed to help countries access, integrate and sequence international environment financing in line with the Paris Declaration on aid effectiveness (Environmental financing: A UNDP perspective).

The government of every state is to finance the charges of budget in support of the conditions of environment or overcoming of negative consequences. This specified obligation of Government of Ukraine is prescribed in the Article 16 of the Constitution of Ukraine, where it is said that providing of ecological safety and maintenance of ecological equilibrium on the territory of Ukraine, overcoming of consequences of the Chernobyl' catastrophe - the catastrophe of planetary scale, maintenance of gene pool of the Ukrainian people are the obligations of the state.

Protection of environment, the rational use of natural resources, providing of ecological safety of activities of man is an integral condition of steady economic and social development of Ukraine. The analysis of dynamics of absolute and computerintegrated indexes of the technogenic loading on environment testifies that the ecological situation in a natural environment, as vitally important environment for existence of man, remains difficult enough.

Financial support for environmental activities is established by law sources and forms of financing of environmental protection environment (Veklich, 2009).

In recent years, fiscal measures have been recognized as one of the primary tools in this economic strategy. Because most countries at first heavily relied on direct regulation and only recently have begun to adopt economic measures on a broad scale, it will be useful to recapitulate the strengths and weaknesses of direct regulation as background for our consideration of fiscal measures for environmental policy (Sanford and Westin, 1991).

\section{Results and discussion}

In order to compare expenditure in the different European countries as well as over time, EPE (Environmental Protection Expenditures) can be expressed in EUR per capita and as a percentage of GDP (or Gross Value Added - GVA - when discussing EPE in the industrial sector).

When expressed as a share of GDP, EPE is an indicator of the total resources a sector is devoting to protecting the environment. As Figure 1 shows, in 2011, specialised producers spent the most on environmental protection in the EU-27.

Their expenditure accounted for $1.19 \%$ of GDP, which was equal to EUR 300 per capita. Industry and the public sector spent roughly the same $(0.41 \%$ and $0.66 \%$ of GDP), which is equal to EUR 104 and EUR 166 per capita respectively. Summing up the expenditure of the three sectors gives a total of $2.26 \%$ of the EU-27's GDP allocated for protecting the environment in 2011. Between 2006 and 2011, EPE grew in the three sectors in absolute and per capita terms. 
Figure 1: EPE by sectors, EU-27, 2011 (\% of GDP)

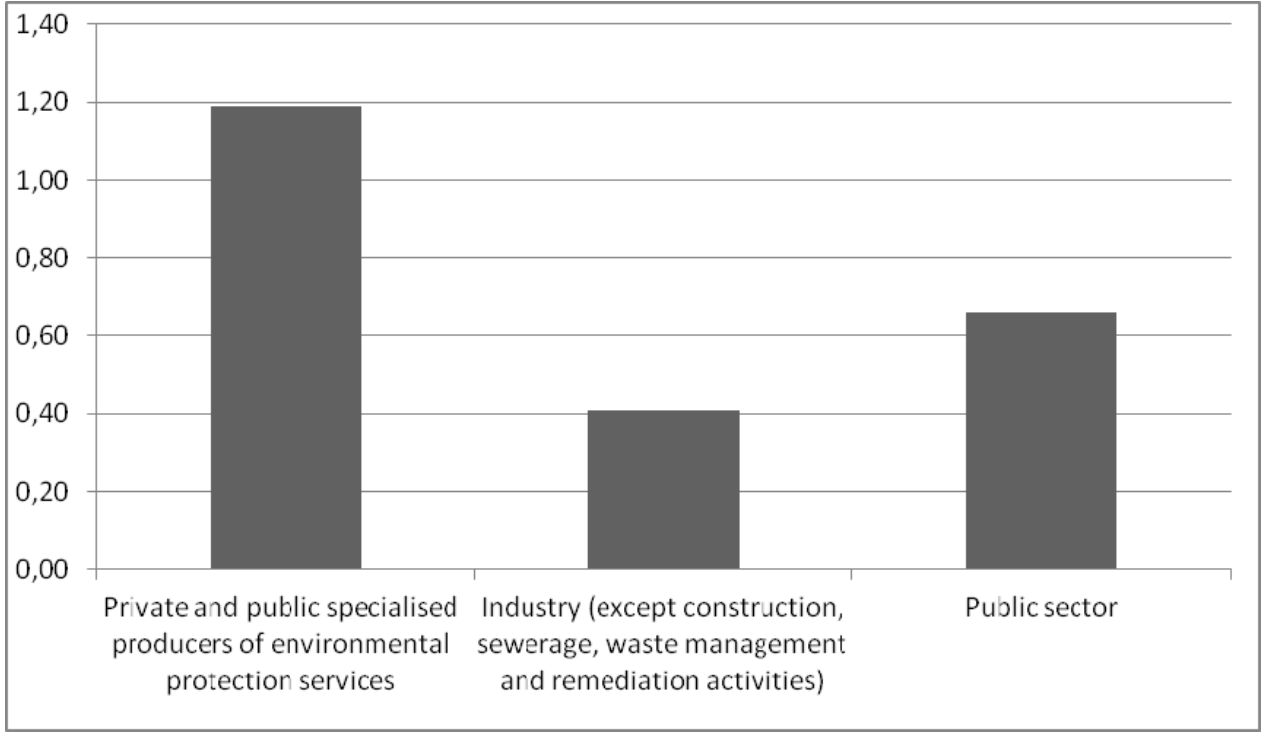

Source: Eurostat (env_ac_exp1), Eurostat (env_ac_exp2) and Eurostat estimates.

For specialised producers, on the other hand, the EPE grew as a share of GDP (Figure 2).

Figure 2: EPE's change by sector, EU-27, 2006 and 2011 (\%)

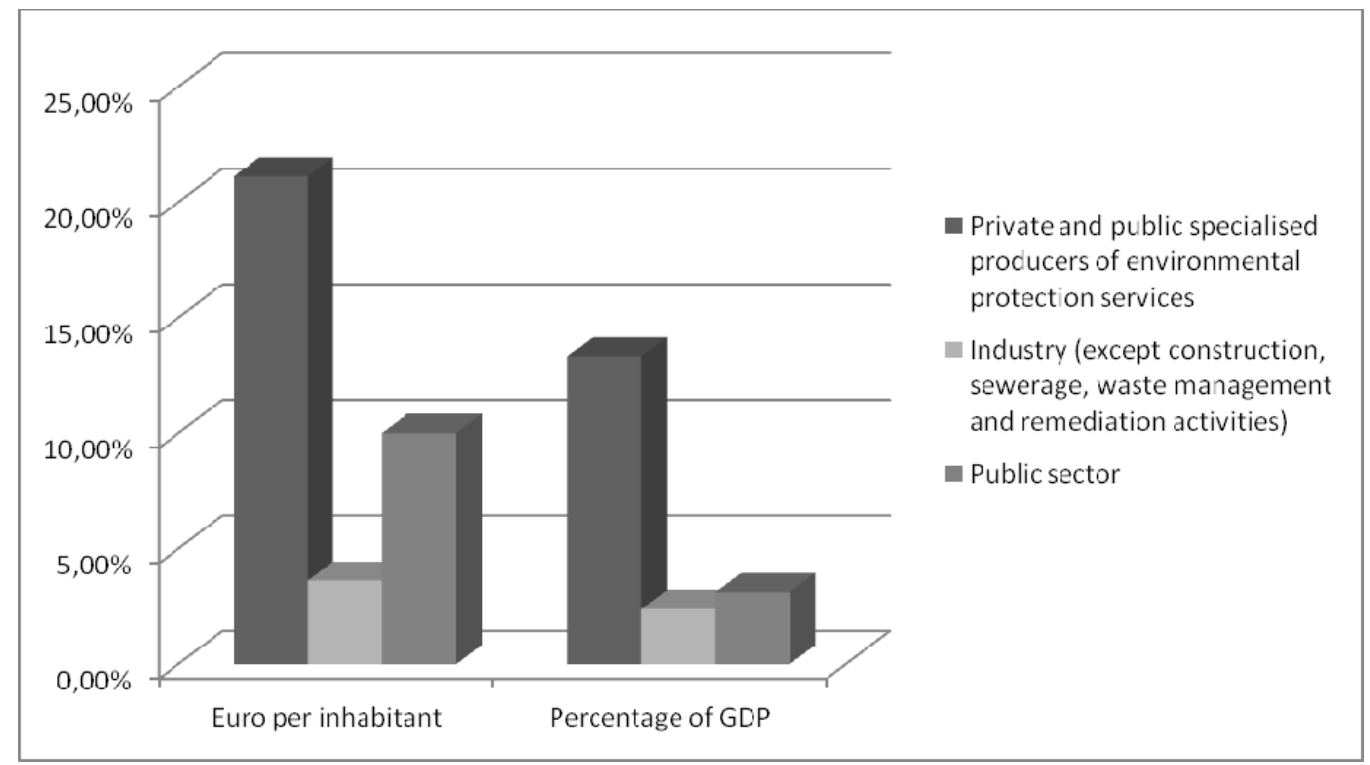

Source: Eurostat (env_ac_exp1), Eurostat (env_ac_exp2) and Eurostat estimates.

These trends have to be interpreted with caution due to the fact that the share of GDP tends to fall if data on EPE are not adjusted for inflation. Nevertheless, the increase of specialised producers' EPE as a share of GDP could be due to the privatisation or semi-privatisation of some environmental activities such as wastewater 
treatment or waste collection in some countries. These environmental activities were mainly carried out by municipalities, and were then turned into private and semi-public corporations so that they now fall into the specialised producers group. The following part of the chapter will explain in detail the evolution and the structure of the EPE within the public sector, specialised producers and industry.

In the EU-27, most of the money spent by the public sector in 2011 went towards providing waste management services, as well as activities related to soil, biodiversity and landscape protection, protection against radiation and research and development. Spending was mostly related to current costs, rather than to investments or subsidies/transfers.

In $2011,42 \%$ of investments and current expenditure made by the public sector in the EU-27 towards protecting the environment against pollution were devoted to non-core domains, $35 \%$ to waste management activities and $20 \%$ to wastewater management (see Figure 3).

Figure 3: Public sector investments and current expenditure by environmental domain, EU-27, 2011 (\% of total public sector investments and current expenditure)

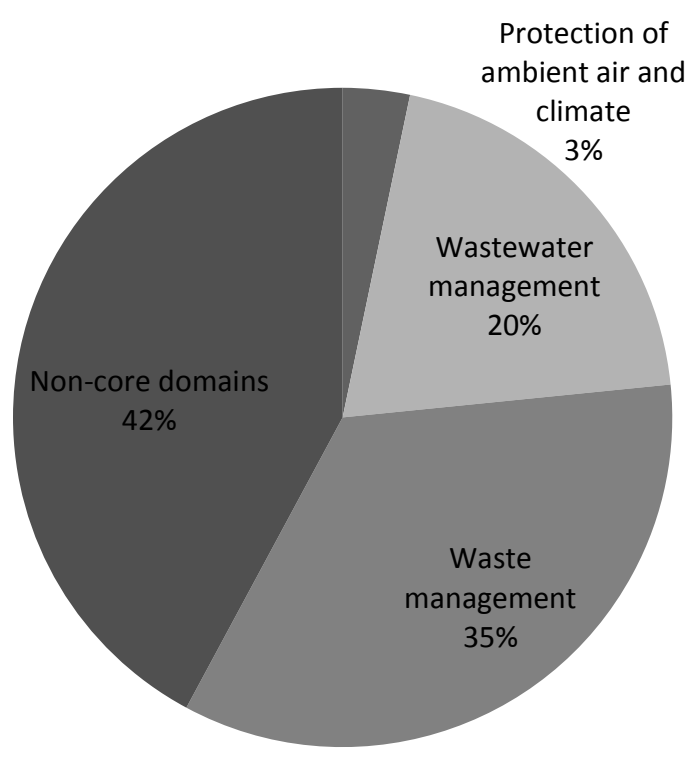

Source: Eurostat (env_ac_exp1) and Eurostat estimates.

Only a fraction of all general government expenditure went towards air protection activities. These activities are in fact mainly carried by industry, since mostly they have to make changes in the industrial production processes in order to reduce and prevent air emissions. Generally speaking, current expenditure has the biggest share in EPE compared to investments and subsidies/transfers. Between 2006 and 2011, the repartition of investments and current expenditure for environmental protection between core and non-core domains remained unchanged.

The main change in the composition of the public sector's investments and current expenditure for environmental protection occurred inside the core domains and relates 
to a shift from wastewater management and air protection activities towards waste management activities (Figure 4).

Figure 4: Public sector EP investments and current expenditure change by environmental domain, EU-27, 2006 and 2011 (\%)

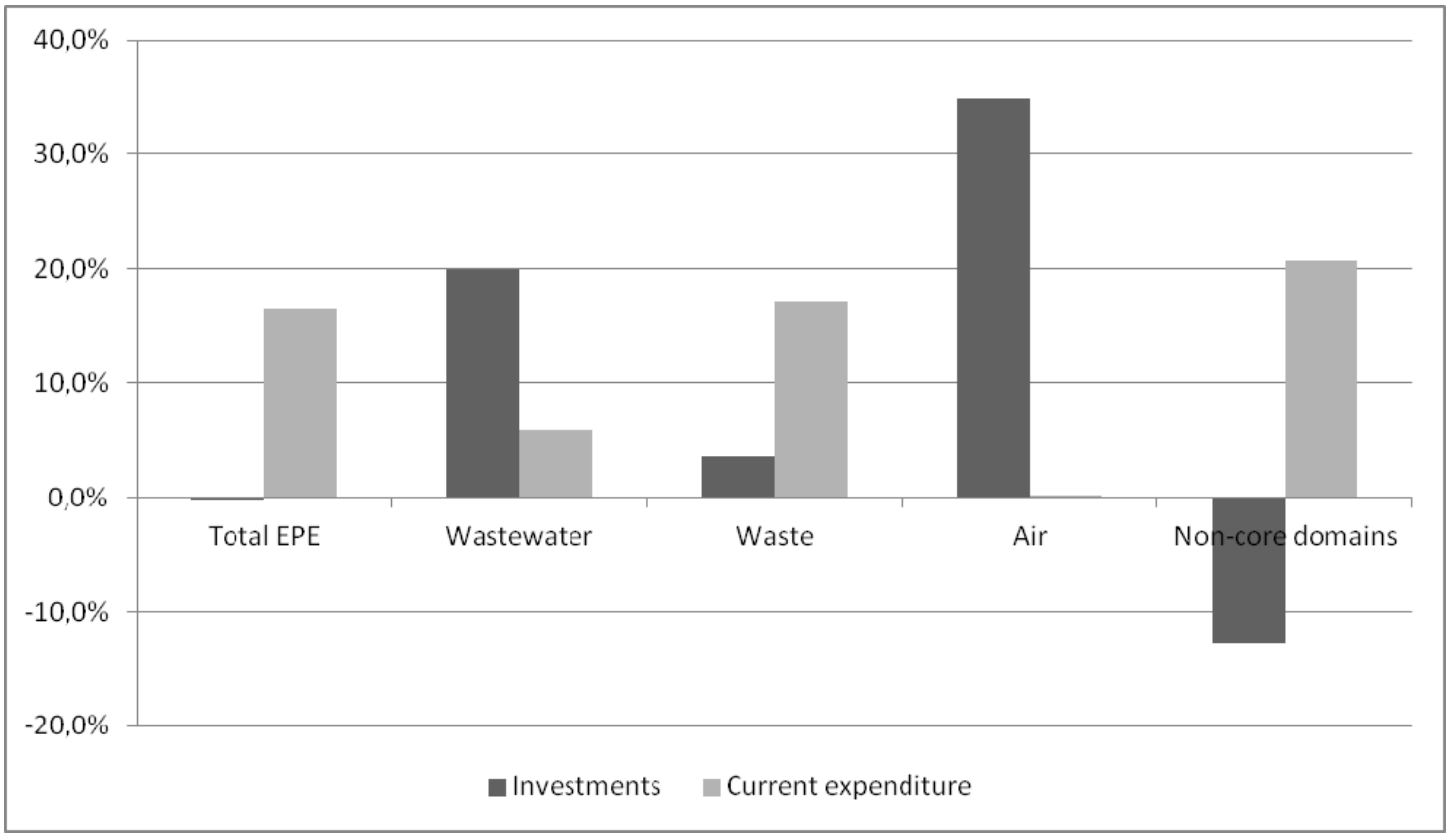

Source: Eurostat (env ac exp1) and Eurostat estimates.

In 2011, compared with 2006, investments for environmental protection slightly dropped by $12 \%$ for the non-core domains, while current expenditure grew, by $20,7 \%$. The dynamic of the public sector's investments and current expenditure for environmental protection can be explained by the fact that the public sector has begun to devote resources to the environmental domains which first received greater regulatory attention, such as problems related to waste, wastewater and air pollution. The implementation of these regulations has strongly relied on investments in end-ofpipe equipment, such as wastewater treatment plants and collecting systems, which now require few additional investments and mainly current expenditure to be carried out. Furthermore, with the increasing presence of specialised producers, the public sector has been investing less and less in environmental protection, as these producers increasingly take over the activities in the waste and wastewater management domains. Public administrations are nowadays shifting their attention and their budget towards other environmental problems such as biodiversity conservation, soil remediation and the reduction of noise. Furthermore, the implementation of the 'polluter pays' principle could be responsible for the reduction of the expenditure in the core domains, since the responsibility for the pollution of air and water and the generation of waste are more easily identified than in the case of biodiversity losses.

In most European countries, the public sector spent between 0.2 and $0.6 \%$ of GDP in 2010 in terms of environmental protection investments and current expenditure. The 
Netherlands, in 2010, devoted almost $1.4 \%$ of its GDP, while in the same year Croatia allocated only $0.07 \%$ of its GDP (Figure 5).

Figure 5: Public sector investments and current expenditure for environmental protection, 2010 (\% of GDP)

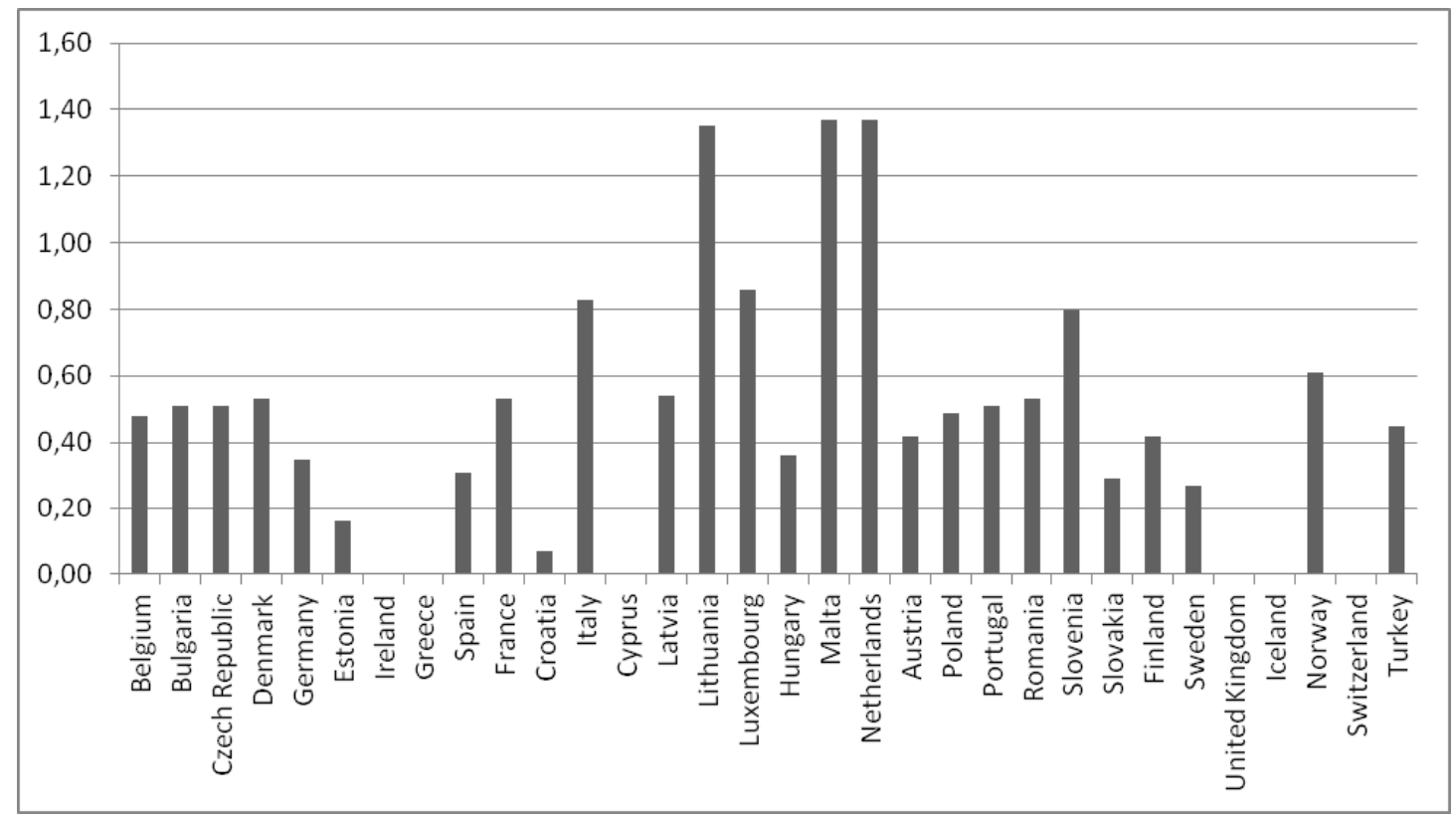

Source: Eurostat (env_ac_exp1)

The share of investments in 'total current expenditure + investments' in most of the new Member States is well above the 25\% EU-27 average (see Figure 6). This is probably due to the high level of expenditure in fixed assets needed to start off activities required by the more stringent EU environmental legislations. For EFTA countries and Turkey, the share of investments in 'total investments + current expenditure is more or less close to the EU-27 average, while in Croatia it is over 95\%.

Wastewater treatment and waste management are generally the main domains in which the public sector spends. However, according to Figure 6, some countries' public sectors spent the most in other domains. This is the case, for example, in Spain, where the public sector principally spent on the protection of biodiversity and other environmental domains. Several countries, like Italy, Cyprus and Spain, classified a relevant part of their general government expenditures as 'other': this includes general environmental administration and management, education, training and information for the environment as well as activities leading to indivisible expenditure and activities not classified elsewhere. Another interesting trend can be seen in Croatia, where more than $95 \%$ of the public sector's investments and current expenditure were devoted to soil and groundwater protection. 
Labenko, O.

Figure 6: Public sector environmental protection investments and current expenditure, 2010 (\% of total investments and current expenditure)

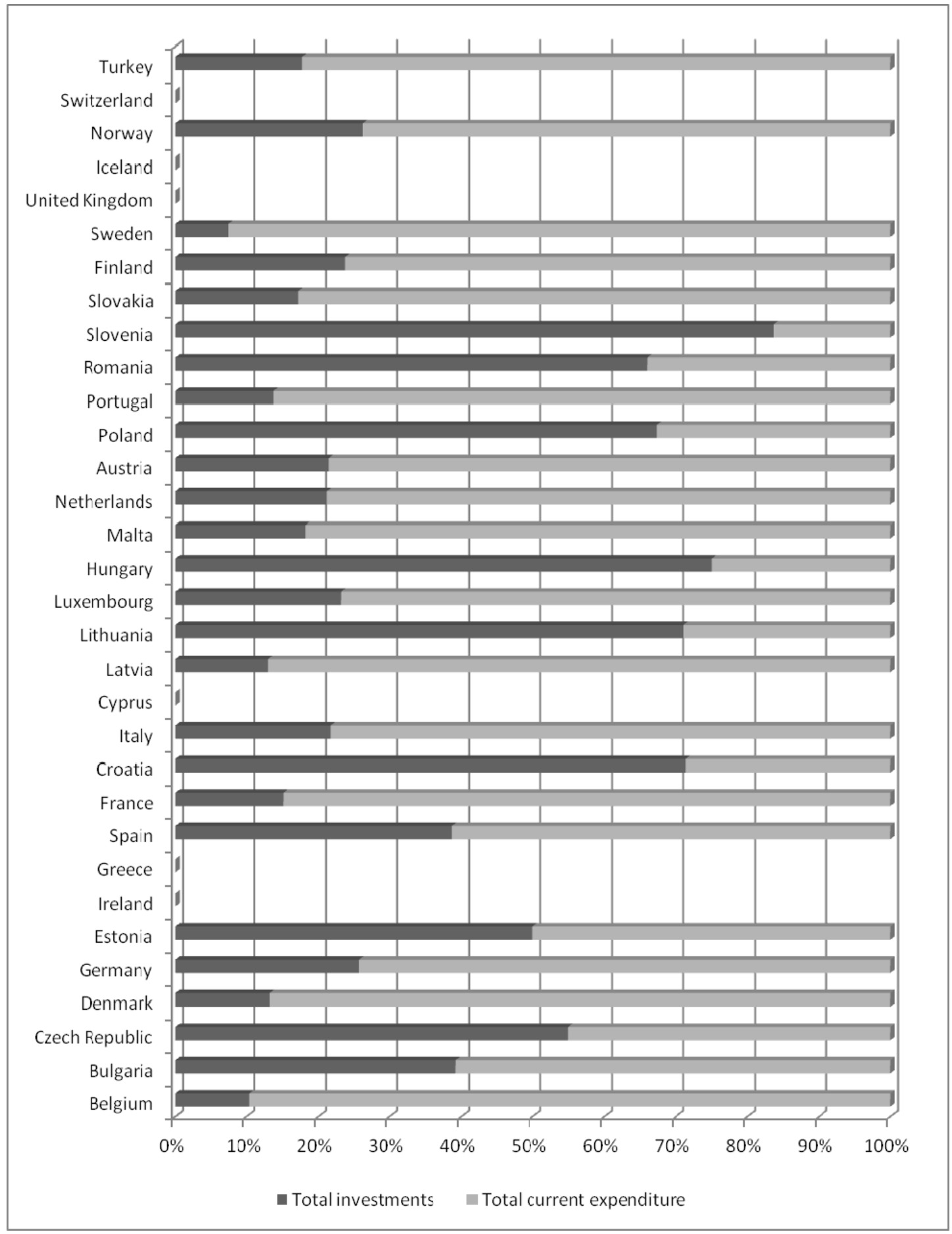

Source: Eurostat (env_ac_exp1) 
Figure 7: Public sector investments and current expenditure by environmental domain, 2010, share of total domains

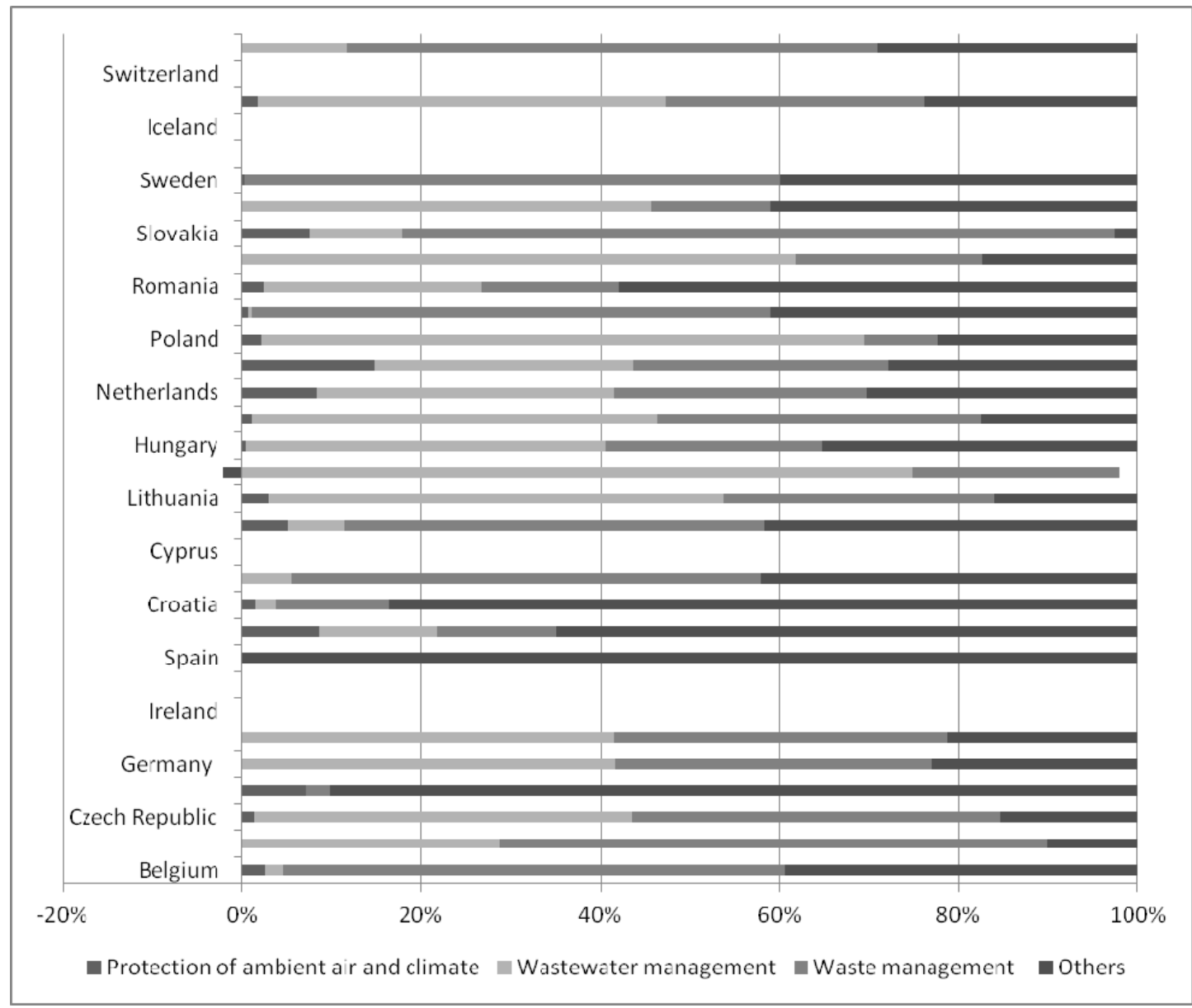

Source: Eurostat (env_ac_exp1)

Environmental conditions get worse from year to year, it is shown in Table 1.

Table 1: Basic indexes of the technogenic impacts on environment in Ukraine, 2005-2011

\begin{tabular}{|l|r|r|r|r|r|r|}
\hline Indexes & $\mathbf{2 0 0 5}$ & $\mathbf{2 0 0 7}$ & $\mathbf{2 0 0 8}$ & \multicolumn{1}{c|}{$\mathbf{2 0 0 9}$} & $\mathbf{2 0 1 0}$ & $\mathbf{2 0 1 1}$ \\
\hline $\begin{array}{l}\text { Emissions of contaminants in air, } \\
\text { thousands tons }\end{array}$ & 6615,6 & 7380 & 7210,3 & 6442,9 & 6678 & 6877,3 \\
\hline $\begin{array}{l}\text { Emissions of dioxide of carbon, } \\
\text { millions tonnes }\end{array}$ & 152 & 218,1 & 209,4 & 185,2 & 198,2 & 234 \\
\hline $\begin{array}{l}\text { Upcast of muddy reverse waters in } \\
\text { the surface water objects, mln/cubic } \\
\text { meter }\end{array}$ & 3444 & 3854 & 2728 & 1766 & 1744 & 1612 \\
\hline Their part in a general drainage, \% & 38,7 & 43,2 & 31,5 & 23 & 21,4 & 20 \\
\hline $\begin{array}{l}\text { Formation of wastes of I-IV classes } \\
\text { of danger, thousands tonnes }\end{array}$ & --- & --- & --- & --- & 419192 & 447641 \\
\hline Including I-III classes of danger & 2411,8 & 2585,2 & 2301,2 & 1230,3 & 1659,8 & 1434,5 \\
\hline
\end{tabular}

Source: http://ukrstat.gov.ua/operativ/operativ2012/ns_rik/analit/arhiv.htm 
Labenko, O.

In a calculation per one square kilometre of territory of country, there are 11 tonnes of the contaminants thrown out in the atmosphere and 22 thousand tonnes of wastes. There is a permanent increase of volumes of pollution in absolute numbers.

The important problem of the use of money on the protection of the environment is absence of feedback, insufficient control of its use.

In Ukraine, financing of the programs of protection and rational use is carried out as capital investments and current costs, their volumes are presented in a Table 2.

Table 2: Dynamics of capital investments and current costs on protection and rational use of natural resources according to directions of nature protection activity

\begin{tabular}{|l|r|r|r|r|r|c|}
\hline & $\mathbf{2 0 0 6}$ & \multicolumn{1}{c|}{$\mathbf{2 0 0 7}$} & \multicolumn{1}{c|}{$\mathbf{2 0 0 8}$} & \multicolumn{1}{c|}{$\mathbf{2 0 0 9}$} & \multicolumn{1}{c|}{$\mathbf{2 0 1 0}$} & $\mathbf{2 0 1 1}$ \\
\hline $\begin{array}{l}\text { Capital investments and current } \\
\text { costs in total }\end{array}$ & 7366,6 & 9691,0 & 12176,0 & 11073,5 & 13128,0 & 18490,5 \\
\hline \multicolumn{1}{|c|}{ Including } & & & & & & \\
\hline $\begin{array}{l}\text { protection of atmospheric air and } \\
\text { climate }\end{array}$ & 1589,3 & 2521,2 & 2826,3 & 2309,0 & 2454,7 & 4011,0 \\
\hline cleaning of reverse waters & 3376,0 & 3904,8 & 4917,1 & 5189,0 & 5770,1 & 6109,7 \\
\hline handling the wastes & 1669,7 & 2157,2 & 2738,2 & 2328,3 & 3075,2 & 5049,8 \\
\hline $\begin{array}{l}\text { protection and rehabilitation of } \\
\text { soil, underground and surface } \\
\text { waters }\end{array}$ & 400,6 & 615,4 & 1074,6 & 641,6 & 796,2 & 1231,9 \\
\hline $\begin{array}{l}\text { reduction of noise and oscillation } \\
\text { influence (except for measures for } \\
\text { labour protection) }\end{array}$ & 47,6 & 76,7 & 89,6 & 25,9 & 11,2 & 70,8 \\
\hline $\begin{array}{l}\text { maintenance of biodiversity and } \\
\text { habitat }\end{array}$ & 97,4 & 139,6 & 210,4 & 225,9 & 255,9 & 347,3 \\
\hline $\begin{array}{l}\text { radiation safety (except for } \\
\text { measures for prevention accidents } \\
\text { and catastrophes) }\end{array}$ & 52,3 & 73,4 & 82,8 & 101,9 & 459,4 & 1347,0 \\
\hline $\begin{array}{l}\text { research works in nature protection } \\
\text { direction }\end{array}$ & 18,4 & 38,0 & 50,6 & 57,1 & 65,3 & 61,4 \\
\hline $\begin{array}{l}\text { other directions of nature } \\
\text { protection activity }\end{array}$ & 115,3 & 164,7 & 186,4 & 194,8 & 240,0 & 261,6 \\
\hline
\end{tabular}

Source: http://ukrstat.gov.ua/operativ/operativ2012/ns_rik/analit/arhiv.htm

Analyzing charges on the protection of natural environment, their absolute increase should be noted. As in 2011, they amounted 18490,5 million hrn. the increase is more than in 2,5 times in comparison with 2006 (7366,6 million hrn.).

It is necessary to notice that the principal cost items on the protection of natural environment in Ukraine (as in 2011) are:

- protection of atmospheric air and climate $(21,7 \%)$;

- cleaning of reverse waters $(33 \%)$;

- handling wastes $(27,3 \%)$;

- protection and rehabilitation of soil, underground and surface waters $(6,7 \%)$;

- other nature protection activity $(1,4 \%)$.

18,4 billion hryvnas was spent on the protection of natural environment by enterprises, organizations and establishments during 2011, of which $65 \%(12,0$ bln 
hryvnas) are current costs on nature protection, related to exploitation and maintenance of facilities of the nature protection importance. $32 \%(6,0 \mathrm{bln} \mathrm{hrn})$ was for investments in the fixed assets directed on building and reconstruction of nature protection objects, acquisition of equipment for implementation of measures of ecological direction and $3 \%(0,8 \mathrm{bln} \mathrm{hrn})$ are costs on major repairs of nature protection equipment. On the cost of funds of State and local budgets $9.81 \%$ of capital investments were developed and $13,93 \%$ of current costs were carried out, and the basic source of financing costs on environment protection, as in previous years, were the personal funds of enterprises, that means $66 \%$ and $86 \%$ respectively.

The state should raise the investment component in the environmental expenditures because maintenance is of such a high level of deterioration requires high operating costs, and their efficiency remains low (Kholod, 2010). One of the sources financing environment protection is ecological payments (see Table 3 ).

During 2011, the enterprises, organizations, establishments were charged by ecological payments for contamination of natural environment, violation of nature protection legislation in a total amount of 1825.6 million hrn., of them 71,8\% (1310.9 million hrn.) is an ecological tax for emissions in the atmosphere from stationary and movable sources, $25 \%(455,4 \mathrm{mln} \mathrm{hrn})$ are collections for placing of wastes and 3,2\% (59,2 million hrn.) is an ecological tax for the upcasts of contaminants into the water objects. Lawsuits as for reimbursement of losses and expenses, caused as a result of violation of nature protection legislation, and fines for administrative crimes in the field of nature protection amount $6,4 \%$ (118,3 million hrn.) respectively.

Table 3. Dynamics of the produced ecological payments (mln hrn)

\begin{tabular}{|l|r|r|r|r|r|r|}
\hline & $\mathbf{2 0 0 6}$ & $\mathbf{2 0 0 7}$ & $\mathbf{2 0 0 8}$ & $\mathbf{2 0 0 9}$ & $\mathbf{2 0 1 0}$ & $\mathbf{2 0 1 1}$ \\
\hline Produced ecological payments total & 871,4 & 980,3 & 1071,4 & 1209,6 & 1209,6 & 1844,0 \\
\hline \multicolumn{1}{|c|}{ of them } & & & & & & \\
\hline $\begin{array}{l}\text { collections for pollution of natural } \\
\text { environments (there is an } \\
\text { ecological tax since 2011) - total }\end{array}$ & 863,5 & 955,7 & 1065,3 & 1198,7 & 1361,2 & 1825,6 \\
\hline $\begin{array}{l}\text { Including } \\
\text { for emissions of contaminants in } \\
\text { the atmosphere }\end{array}$ & 501,9 & 558,7 & 627,1 & 702,2 & 795,9 & 1310,9 \\
\hline $\begin{array}{l}\text { for the upcasts of contaminants } \\
\text { directly into the water objects }\end{array}$ & 69,8 & 75,0 & 69,7 & 88,0 & 93,7 & 59,2 \\
\hline $\begin{array}{l}\text { for placing of wastes (except for } \\
\text { radio-active) }\end{array}$ & 291,8 & 322,0 & 368,5 & 408,5 & 471,6 & 455,4 \\
\hline $\begin{array}{l}\text { Penalty for violation nature } \\
\text { protective legislation }\end{array}$ & 7,9 & 24,6 & 6,1 & 10,9 & 147,5 & 118,3 \\
\hline
\end{tabular}

Source: http://ukrstat.gov.ua/operativ/operativ2012/ns_rik/analit/arhiv.htm

The volumes of provided ecological payments are ten times smaller than expenses on protection and support of the environment. It can prove the present potential to the increase of ecological payments both in absolute and in relative expression in the structure of earnings of the state budget. Such increase is possible due to transferring 
of the tax burden from labour and capital on ecological taxation, which will assist in strengthening of ecological function of taxes.

The increase of sum of financing of expenses on the protection of the environment cannot testify to their sufficiency, that is why we will compare the volumes of the noted expenses to data of some countries of EU, namely Poland, Czech Republic, Slovakia, Hungary and EU on the whole.

Current expenditure for environmental protection include payments to keep environmental departments running, staff costs and other costs for daily activities within the domain of environment.

In of order to compare expenditure in different European countries as well as over time, EPE can be expressed in euro per capita (Figure 8) and as a percentage of GDP (Figure 9).

When expressed as a share of GDP, EPE is an indicator of the total resources a sector devoted to protecting the environment.

Figure 8: Environmental protection expenditure - indicators: \% of GDP

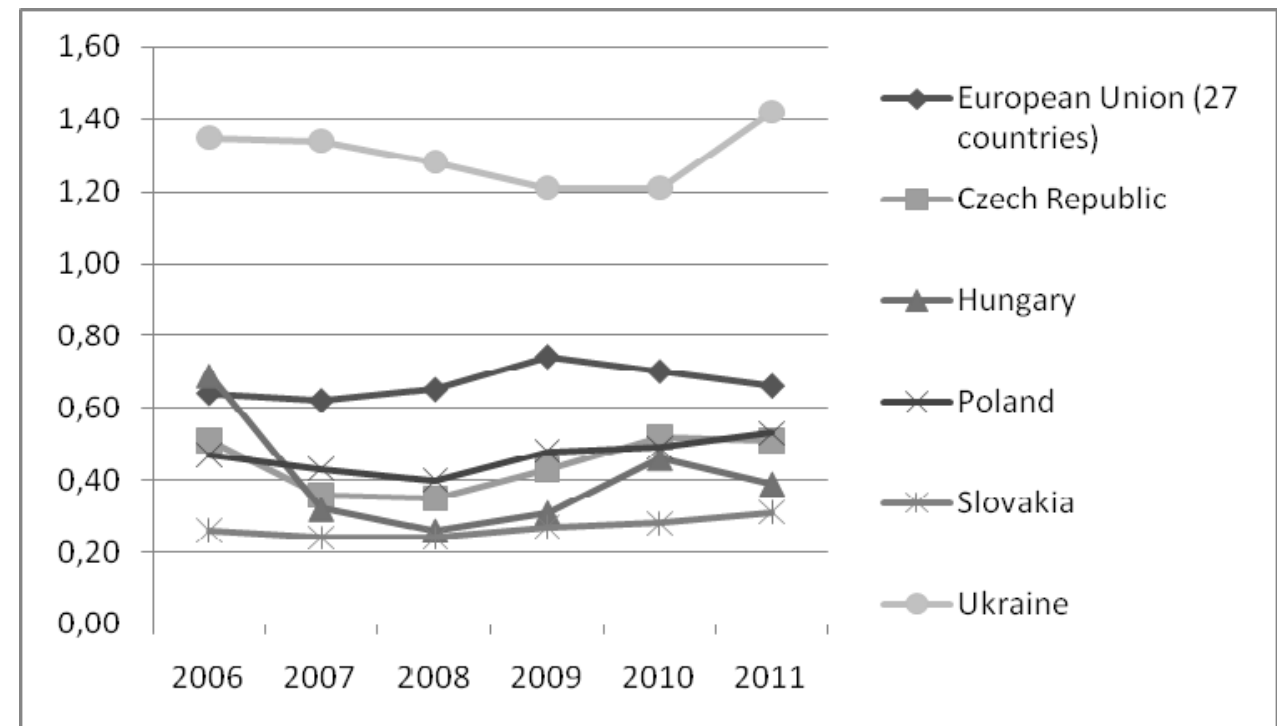

Source:http://epp.eurostat.ec.europa.eu/cache/ITY_OFFPUB/KS-32-10-283/EN/KS-32-10-283-EN.PDF and http://ukrstat.gov.ua/operativ/operativ2012/ns_rik/analit/arhiv.htm

Comparing of share of charges on protection of the environment in GDP testifies to its considerable advantage in Ukraine in comparing to all other countries $(1,2-1,4 \%)$. The smallest share of expenses on protection of the environment is observed in Slovakia $(0,2-0,3 \%)$. The middle level of expenses on protection of the environment in EU presents $0,6-0,7 \%$ during an analyzed period which is the greater index than in the studied countries of EU. 
Figure 9: Environmental protection expenditure - indicators: Euro per capita

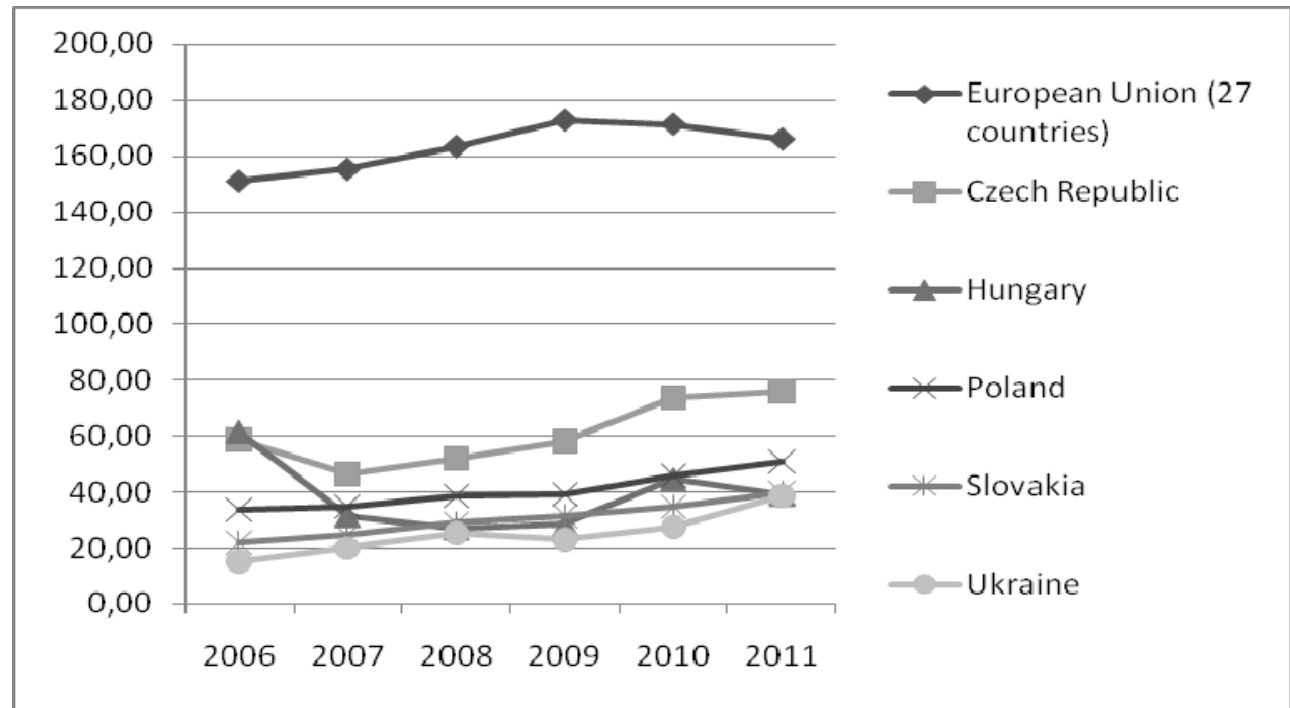

Source: http://epp.eurostat.ec.europa.eu/cache/ITY_OFFPUB/KS-32-10-283/EN/KS-32-10-283EN.PDF and http://ukrstat.gov.ua/operativ/operativ2012/ns_rik/analit/arhiv.htm

When we examine the sums of expenses on protection of the environment in a calculation per capita, it is possible to witness a reverse situation than in $\%$ to GDP. Therefore, an index of Ukraine is the smallest among all the studied countries (about 40 Euro per capita in 2011). The highest index of expenses per capita among the considered countries is in Czech Republic, namely 75 Euros in 2011 meanwhile the sum of the noted expenses is considerably higher on the average in the countries of EU and presents 166 Euros in 2011.

\section{Conclusions}

Environmental protection expenditure measures include all actions and activities that are aimed at the prevention, reduction and elimination of pollution, as well as any other degradation of the environment. Thus, it is an indicator of the commitment of society to protect the environment. Three sectors - the public sector, private and public specialised producers and industry - account for most of the environmental expenditure. In 2011, the expenditure for protecting the environment in the EU-27 by these three sectors was equal to $2.26 \%$ of GDP.

In the EU-27 in 2011, most of the money spent by the public sector went towards providing waste management services and services in the noncore domains. The EPE of specialised producers was mainly directed towards waste and wastewater management activities. Industrial EPE in most European countries was evenly distributed among environmental domains. For many years, European statistical services have collected data on air pollution, energy, water consumption, wastewater and solid waste and on their management, in addition to environmental data of an economic nature, as environmental expenditure. The links between all these data enable policymakers to consider the environmental impacts of economic activities 
(resource consumption, air or water pollution, waste production) and to assess the actions (investments, technologies, expenditure) carried out to limit the causes and risks of pollution. Eurostat has worked towards systematising the gathering of environmental statistics about the activities of all economic sectors within the EU. These statistics are used to assess the effectiveness of new regulations and policies. The second use of these statistics is for the analysis of the links between the pressures on the environment and the structure of the economy. Harmonised, comparable and comprehensive statistics about environmental expenditure and the sectors funding that expenditure should help to improve policy-makers' decisions.

Thus, it should be noted that the volumes of contamination in countries, which were selected for comparison, reduce on a background of the increase of GDP that can testify a more effective use of financial resources for environmental protection. GDP is the basic factor of possible increase of volumes of contamination. In Ukraine vice versa, together with the increase of volumes of financial resources on protection of the environment the volumes of contamination grow.

The above-mentioned proves, that in the considered countries of EU reducing of volumes of contamination of the environment is observed, and in Ukraine there is an increase; the relative value and absolute sum of expenses on protection of the environment grows in all the analysed countries; and finally, despite the prevailing relative share of expenses on protection of the environment in attitude to GDP in Ukraine, the noted expenses in an absolute sum per capita are the smallest, it can testify to potential increase of such expenses.

On a background of the increase of the volume of contamination in Ukraine during an analysed period, there is an increase of sum of expenses on protection of the environment, it can testify, on the one hand, about insufficiency of sum of financing, on the other hand, about inefficiency of such type of financing.

\section{References}

1. Kholod, M. (2010): Analysis of the state fund for environmental protection in the context of Ukraine's transition to environmentally sustainable development «Economical sciences"Series „Accounting and Finance”. Issue 7 (25), Part 5.

2. Gaines, S.E.; Westin, R.A. (eds) (1991): Taxation for environmental protection: a multinational study. Quorum Books, Westport, USA, $256 \mathrm{p}$.

3. Veklich, O. (2009): Modern trends in financial support environmental performance in Ukraine/ Journal «Finance of Ukraine», №11.

4. Ban Ki-moon (2007): speech of UN Secretary General, 3 Dec 2007, Washington Post

5. Environmental financing: A UNDP perspective https://www.un.org/ga/president/62/issues/environmentalgov/swisspresentation.pdf

6. The Organisation for Economic Co-operation and Development (OECD), Development Assistance Committee (DAC) http://www.oecd.org/dac/developmentassistancecommitteedac.htm

7. Environmental statistics and accounts in Europe/ European Commission/ Luxembourg: Publications Office of the European Union 2010, 342 p. 